Int. J. Electrochem. Sci., 14 (2019) 3777 - 3791

\title{
Reaction/Diffusion Equation with Michaelis-Menten Kinetics in Microdisk Biosensor: Homotopy Perturbation Method Approach
}

\author{
R.Swaminathan ${ }^{1}$, K. Lakshmi Narayanan ${ }^{2}$, V.Mohan $^{3}$, K.Saranya $^{3}$, L.Rajendran $^{4, *}$ \\ ${ }^{1}$ Department of Mathematics, Vidhyaa Giri College of Arts and Science, Puduvayal,Tamilnadu \\ ${ }^{2}$ Department of Mathematics, Sethu Institute of Technology, Kariyapati, Tamilnadu \\ ${ }^{3}$ Department of Mathematics, Thiagarajar College of Engineering, Madurai,Tamilnadu \\ ${ }^{4}$ Department of Mathematics, AMET (Deemed to be University), Chennai, Tamilnadu \\ *E-mail: raj_sms@rediffmail.com
}

doi: $10.20964 / 2019.04 .13$

Received: 27 November 2018 / Accepted: 7 January 2019 / Published: 10 March 2019

This paper presents the non steady state model of a microdisk enzyme based biosensor where the enzyme reacts directly on the electrode itself. The model is based on diffusion equation containing a non-linear term related to Michaelis-Menten kinetics of enzymatic reaction. We have reported for the first time the utilization of new approaches of the homotopy perturbation method (HPM) to solve nonlinear partial differential equations in microdisk biosensor. Our analytical solution was also compared with numerical solutions and satisfactory agreement was noted. The influence of various parameters on the concentration are also discussed.

Keywords: Biosensors, Mathematical model, Homotopy perturbation method, Nonlinear equation,Chemical sciences.

\section{$\underline{\text { FULL TEXT }}$}

(C) 2019 The Authors. Published by ESG (www.electrochemsci.org). This article is an open access article distributed under the terms and conditions of the Creative Commons Attribution license (http://creativecommons.org/licenses/by/4.0/). 